\title{
Vegetative rescue of Camu-Camu from epicormic sprouts of detached branches
}

\author{
Natália Neves de Lima로 Sidney Alberto do Nascimento Ferreira², \\ Jônathan Brito Fontoura Conceição ${ }^{3}$
}

\begin{abstract}
The cloning of camu-camu by cuttings has shown distinct and sometimes controversial results. The use of juvenile materials has been indicated for difficult rooting species. Thus, this work aimed to evaluate the emission of epicormic sprouts in mega-cuttings and cuttings of detached branches, as well as the cloning of camu-camu from these sprouts. The research was developed by conducting four experiments, the first two being related to the emission of epicormic sprouts, while the others referred to the cloning of camu-camu from these sprouts. In experiments evaluating sprout emission, the following factors were studied: mother plant $\mathrm{x}$ branch position; mother plant $\mathrm{x}$ substrate. In the other tests, using standard cuttings with two pairs of leaves made from epicormic sprouts, the following factors were evaluated: mother plant $\mathrm{x}$ cutting type $\mathrm{x}$ indolbutyric acid concentration (IBA); mother plant $x$ hydroretentive polymer $x$ environment. The number and speed of sprouts vary depending on the mother plant. IBA has negative influence on cutting and cuttings from the lower portion of sprouts have greater rooting potential than those from the upper portion. Environment with intermittent mist irrigation is more suitable for the propagation of camu-camu by cuttings. Vegetative rescue by means of epicormic sprouts in mega-cuttings and cuttings of detached branches presents potential application for the clonal propagation of camu-camu, requiring improvement in order to increase efficiency.
\end{abstract}

Index terms: Myrtaceae, Myrciaria dubia, vegetative propagation, cuttings, rooting.

Corresponding author: nat.neves08@gmail.com

Received: February 26, 2020 Accepted: May 26, 2020

Copyright: All the contents of this journal, except where otherwise noted, is licensed under a Creative Commons Attribution License.

(cc) $\mathrm{EY}$

\section{Resgate vegetativo do Camu-Camu a partir de brotações epicórmicas de ramos destacados}

Resumo - A clonagem do camu-camu por estaquia tem apresentado resultados distintos e às vezes controversos. O emprego de material juvenil tem sido indicado para espécies de difícil enraizamento. Assim, este trabalho teve como objetivo avaliar a emissão de brotações epicórmicas em megaestacas e estacas de ramos destacados, bem como a clonagem do camu-camu a partir dessas brotações. A pesquisa foi desenvolvida por meio de quatro experimentos, sendo os dois primeiros relacionados com a emissão de brotações epicórmicas, enquanto os demais se referiram à clonagem do camu-camu a partir dessas brotações. Nos experimentos de emissão de brotações, foram estudados os fatores: matriz x posição do ramo; matriz x substrato. Nos demais ensaios, utilizando estacas padronizadas com dois pares de folhas, confeccionadas a partir das brotações epicórmicas, foram avaliados os fatores: matriz x tipo de estaca $\mathrm{x}$ concentração de ácido indolbutírico (AIB); matriz x polímero hidrorretentor $\mathrm{x}$ ambiente. O número e a velocidade de brotação variam em função da planta-matriz. O AIB influencia negativamente a estaquia, e estacas da porção basal da brotação apresentam maior potencial de enraizamento em relação às da porção superior. $\mathrm{O}$ ambiente com irrigação por nebulização intermitente é mais adequado para a propagação do camu-camu por estaquia. $\mathrm{O}$ resgate vegetativo por meio de brotações epicórmicas, em megaestacas e estacas de ramos destacados, apresenta potencial de aplicação para a propagação clonal do camu-camu, necessitando de aperfeiçoamento a fim de elevar sua eficiência.

Termos para indexação: Myrtaceae, Myrciaria dubia, propagação vegetativa, estaquia, enraizamento.

\footnotetext{
${ }^{1}$ Master, National Institute for Research in the Amazon - Manaus-AM, Brazil. Email: nat.neves08@gmail.com(ORCID 0000-0002-0244-9704) ${ }^{2} \mathrm{PhD}$, Researcher at the National Institute for Research in the Amazon - Manaus-AM, Brazil. Email: sanf@inpa.gov.br ${ }^{\text {(ORCID 0000-0002-4156- }}$ 9733)

${ }^{3}$ Master, Field Technician / PCI Researcher at the National Institute of the Atlantic Forest - Santa Teresa-ES, Brazil. Email: johnbrito.jbfc@ gmail.com ${ }^{\text {(ORCID } 0000-0002-2017-4126)}$
} 


\section{Introduction}

Camu-camu [Myrciaria dubia (Kunth) McVaugh] is a woody shrub belonging to the Myrtaceae family, which occurs naturally at riversides and lakesides of the Amazon basin, withstanding annual floods of up to five months (PETERS; VASQUEZ, 1987; PANDURO et al., 2001). It is distributed in Peru, Brazil, Venezuela and Colombia, but it occurs with greater abundance in the Peruvian Amazon, where there are extensive natural populations (PETERS; VASQUEZ, 1987). It has high economic potential due to its high content of ascorbic acid (vitamin C), which can

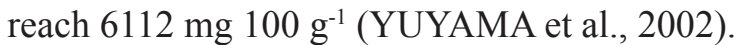

The propagation of camu-camu is usually carried out sexually via seeds (GENTIL et al., 2004), resulting in uneven plants, with wide variation in architecture and production, which is not desired in the establishment of commercial plantations (CHAGAS et al., 2012). Thus, vegetative or asexual propagation of the species assumes importance, considering that this method allows obtaining uniformity, precocity and maintenance of the mother plant characteristics (HARTMANN et al., 1996).

Camu-camu can be asexually propagated by grafting, cutting and air layering methods, highlighting the first method, which allows obtaining up to $90 \%$ of graft setting (NASCIMENTO, 2018). According to this author, through cutting, seedlings can be obtained in a short period of time, about 5 to 6 months. However, cuttings have shown rooting difficulties, even when submitted to the action of phytoregulators (SILVA et al., 2009). Cruz (2005) has demonstrated viability, with approximately $55 \%$ rooting, in cuttings immersed for 48 hours in 400 $\mathrm{mg} \mathrm{L}^{-1}$ indolbutyric acid (IBA) + naphthalene acetic acid (NAA) solution.

Several factors can affect root formation, among which age of the mother plant, type of cutting, genetic rooting potential, hormonal balance, health and environmental factors, such as temperature, humidity, light and substrate (FACHINELLO et al., 2005). In several species of the Myrtaceae family, the absence of adventitious rooting of cuttings is associated with the presence of chemical inhibitors such as essential oils (KIBBLER et al., 2002).

To favor and increase the rooting of cuttings, the use of phytoregulators and environment with intermittent mist is recommended (FACHINELLO et al., 2005; CHAGAS et al., 2012). Hydroretentive polymer has been used to increase the availability of water in the substrate, in addition to decreasing the amount of water supplied and increasing the quality of seedlings (NAVROSKI et al. 2015). This polymer has favored the rooting of Eucalyptus spp. (AZEVEDO et al., 2015), blackberry (Rubus sp.) (MOREIRA et al., 2012) and sweet passion fruit cuttings (Passiflora alata) (HAFLE et al., 2008). In addition, the use of juvenile materials is indicated for species with difficult rooting (FACHINELLO et al., 2005).

The use of epicormic sprouts, a material with juvenile characteristic, is a technique that can be used in the rescue of adult plants through stem ringing and cutting or by detached branches (BORGES JUNIOR et al., 2004; WENDLING et al., 2013; STUEPP et al., 2016; NASCIMENTO et al., 2018). This technique has shown satisfactory results in the production of cuttings, with greater rooting potential in species such as Ilex paraguariensis (BITENCOURT et al., 2009; STUEPP et al., 2017), Vochysia bifalcata (RICKLI et al., 2015), and Eucalyptus spp. (ALMEIDA et al., 2007; BACCARIN et al., 2015).

In view of the above, this study aimed to evaluate the emission of epicormic sprouts in mega-cuttings and cuttings of detached branches, as well as the cloning of camu-camu from these sprouts.

\section{Material and methods}

\section{Origin of the material and study location}

The research was developed through four experiments; the first two were related to the emission of epicormic sprouts, while the others referred to cloning from sprouts obtained. The branches used were from plants in two environmental conditions with periodic flooding: floodplain area (Gleysoil) of the "Ariaú" Experimental Station, belonging to the National Institute for Research in the Amazon (INPA), located in municipality of Iranduba, AM, on the left bank of the Solimões River ( $3^{\circ} 15^{\prime} 11.98^{\prime \prime}$; $60^{\circ} 14^{\prime} 37.31^{\prime \prime} \mathrm{W}$ ); and igapó area (Quartz sand) in front of the Soka-CEPEAM Institute (Center for Environmental Studies and Projects of the Amazon), located on the left bank of the mouth of the Negro River, municipality of Manaus, AM (36'53.58” S; 59 54'17.35”'W).

Experiments were carried out in the seedling nursery of the Biodiversity Coordination of INPA, in Manaus, AM (35'29.69"S; 5959'34.48”W), which was covered with $70 \%$ shade screen and transparent plastic film (150 microns), and floor covered with pebble and intermittent mist irrigation system controlled by evaporation scale.

\section{Experiment 1}

The experimental design used was completely randomized in a 10 (mother plant) x 5 (mega-cutting positions) factorial scheme with four replicates, with one mega-cutting per plot.

In the floodplain area, ten cultivated plants (derived from seeds aged 34 years) were randomly selected and, from each of these, four basal branches (emitted at ground level) were removed, cut at approximate height of $15 \mathrm{~cm}$ from the ground. Then, they were sectioned in $40 \mathrm{~cm}$ mega-cuttings, stratified into five classes according to 
position in the branch from the basal part: $0-40 \mathrm{~cm}$; 40$80 \mathrm{~cm} ; 80-120 \mathrm{~cm} ; 120-160 \mathrm{~cm}$; and $160-200 \mathrm{~cm}$. After cutting, mega-cuttings were packed in polypropylene bags and transported to the seedling nursery.

Prior to the implementation of the experiment, the upper end of mega-cuttings was dipped in heated paraffin in order to decrease water loss. Subsequently, they were vertically placed in plastic boxes $(43 \mathrm{~cm} \times 63 \mathrm{~cm} \times 18$ $\mathrm{cm})$ drained (with holes at the bottom), containing sand, $10 \mathrm{~cm}$ from the base of the buried mega-cutting. After the implementation of the experiment, sprout emission was counted every 5 days, for 90 days, which occurred in isolation or in groups of two to three units, arising from the same point (dormant auxiliary sprout). For purposes of registration, the total number of sprouts per mega-cutting was considered, not taking into account whether they were isolated or grouped. From these data, the sprouting speed index adapted from Maguire (1962), and the mean sprouting time adapted from Labouriau (1983) were calculated.

\section{Experiment 2}

The experimental design used was completely randomized in an 8 (mother plants) x 2 (substrates) factorial scheme with four replicates, with five cuttings per plot.

From the canopy of eight mother plants occurring in igapó (from natural seed dispersion), standardized cuttings were collected, with $20 \mathrm{~cm}$ in length and $9.6( \pm 1.5)$ $\mathrm{mm}$ in diameter. After collection, they were transported to the nursery in polypropylene bags. Subsequently, they were immersed in sodium hypochlorite solution $(0.5 \%)$, for five minutes. Then, they were washed in running water for another five minutes.

The upper end of cuttings was dipped in heated paraffin, and then vertically placed in tubes $\left(280 \mathrm{~cm}^{3}\right)$, with $5 \mathrm{~cm}$ from their buried base. Two types of substrates were used: Vivatto Slim Plus ${ }^{\circledR}$ commercial substrate, composed of bio-stabilized pine bark, vermiculite, charcoal grinder, water and phenolic foam; and non-commercial substrate, consisting of litter, clay soil and sand (4: 2: 1, v: v: v).

After the implementation of the experiment, sprouts were counted every 5 days, for 85 days, not taking into account whether they were isolated or grouped, in the same way as in the previous experiment. From this data, the sprouting speed index and the mean sprouting time were calculated, according to the first experiment.

\section{Experiment 3}

The experimental design used was completely randomized in a 2 (mother plants) $\mathrm{x} 2$ (types of cuttings) $\mathrm{x} 4$ (IBA concentrations) factorial scheme, with three replicates, each containing five cuttings.

Epicormic sprouts of mother plants from the igapó area were used. From these, two types of cuttings with two pairs of leaves were made: basal (with the lower end close to the original mega-cutting); and upper (removed just above the previous cutting). Basal leaves were eliminated and those on the top had their leaf blade reduced to half. During the process of collecting epicormic sprouts and preparing cuttings, all the material was kept in plastic container containing water to avoid withering.

The cuttings in each position (basal and upper) were treated with indolbutyric acid (IBA) at concentrations of $0,500,1,000$ and $2,000 \mathrm{mg} \mathrm{kg}^{-1}$, using inert talc as vehicle. In treatment with IBA, the lower portion of cuttings was inserted in the growth regulator, removing the excess, and then planting was carried out in 98-cell plastic trays $\left(30 \mathrm{~cm}^{3} \mathrm{cell}^{-1}\right)$, containing a mixture of litter, clay soil and sand as substrate (4:2:1, v: v: v). Cuttings were kept in nursery for 90 days, when the following variables were evaluated: survival, sprout emission, callus formation and rooting.

\section{Experiment 4}

The experimental design used was completely randomized in a 3 (mother plants) $\mathrm{x} 2$ (environments) $\mathrm{x}$ 2 (hydroretentive polymer) factorial scheme with three replicates, each containing five cuttings.

Epicormic sprouts used were from mother plants originating from the igapó area. From these, standard cuttings with two pairs of leaves were made, basal leaves were eliminated and those on the top had their leaf blade reduced to half. During the process of collecting epicormic sprouts and preparing cuttings, all the material was kept in plastic container containing water to avoid withering.

The substrate used was a mixture of litter, clay soil and sand (4: 2: 1, v: v: v), separated into two parts, according to the absence or presence of hydroretentive polymer (Forth Gel ${ }^{\circledR}$ at dose of $2 \mathrm{~g} \mathrm{~L}^{-1}$, incorporated into the substrate in its dehydrated form). Cuttings were kept in mini-greenhouse or under intermittent mist. The mini-greenhouse was made using transparent $2 \mathrm{~L}$ pet bottles with removable upper part for irrigation purposes; perforated bottom and unscrewed cap (half turn) to allow gas exchange, kept in nursery with $70 \%$ shading. Each pet bottle constituted an experimental unit and irrigation was carried out at intervals of 5 days, with 5 water sprays. In the environment (nursery) with intermittent mist, containers were the same, but without the top of the bottle. Cuttings were maintained under these conditions for 90 days, when the following variables were evaluated: survival, sprout emission, callus formation and rooting.

\section{Statistical analyses}

In experiments 1 and 2, data obtained up to the average periods of greatest sprout emission, 60 and 50 days, respectively, were considered. For the purpose of analysis, variables were submitted to the normality test (Shapiro-Wilk) and, when necessary, count data were 
transformed into $\sqrt{\mathrm{x}}$ (or $\sqrt{\mathrm{x}}+0.5$, if there was zero), while those of percentage into sine arc $V_{x} / 100$. After analysis of variance, applied for significant differences, treatment averages were compared by the Tukey test at $5 \%$ probability level. Regression adjustment was made when significant difference among levels of quantitative factor was observed. Statistical analyses were performed using the Assistat 7.7 beta software (SILVA; AZEVEDO, 2016).

\section{Results and discussion}

\section{Experiment 1}

Mega-cuttings had average diameter of $47( \pm 8.1)$ $\mathrm{mm}$, with little variation between classes. The emission of epicormic sprouts started between 10 to 15 days after the implementation of the experiment, and between 20 to 25 days, most mother plants and mega-cutting positions had already emitted sprouts, except for mother plant 1 , which started between 25 to 30 days (Figure 1). In species such as Eucalyptus cloeziana and Ilex paraguariensis, the emission of epicormic sprouts started later, at 40 days (ALMEIDA et al., 2007) and between 30 to 60 days (NASCIMENTO et al., 2018), respectively. Between 40 and 50 days, emissions of sprouts started to stabilize; however, the maximum potential of emitted sprouts was on average at 60.4 days ( \pm 15.3 ). After this period, a decline in the emissions of sprouts was observed, which was shown to be associated with the drying and falling of newer sprouts (recently emitted). Wendling et al. (2009) evaluated epicormic sprouts in Araucaria angustifolia and observed that there was a decrease in the number of sprouts between 60 and 90 days, with subsequent mortality of almost $100 \%$ of them, at 120 days. This reduction may be associated with the exhaustion of reserves present in branches and competition for water, nutrients, space and light between sprouts (WENDLING et al., 2009; DIAS et al., 2015). Nascimento et al. (2018) reported that in Ilex paraguariensis mega-cuttings, with approximately $70 \mathrm{~cm}$ in length, the decrease in sprouts occurred in the period between 180 to 210 days.

The number of sprouts and the sprouting speed index did not show significant differences for the mother plant $x$ mega-cutting position interaction, but only for the mother plant factor. In this factor, the mean sprouting time cannot be estimated due to the fact that several mother plant $\mathrm{x}$ mega-cutting position combinations (Figure 1) have presented null results (no sprouting), which made the calculation of this variable unfeasible.

The number of sprouts per mega-cutting was quite variable among plants, with emphasis on mother plant 5 , which was superior compared to the others, with average of 18.6 sprouts per mega-cutting (Table 1). In contrast, mother plants 1 and 8 had the lowest averages, with less than one sprout per mega-cutting. Regarding the mega-cutting position, which did not show significant differences in the different levels under study, the average number of sprouts was 6 units.

Table 1. Average number of epicormic sprouts (NEB) and sprouting speed index (SSI), referring to the mega-cutting of detached branches from different mother plants and mega-cutting positions obtained during the 60-day observation period under nursery conditions with intermittent mist system in Manaus, AM.

\begin{tabular}{ccc}
\hline Factors & NEB & $\begin{array}{c}\text { SSI } \\
(\text { sprout day }\end{array}$ \\
\hline Mother plant (M) & $0.9 \mathrm{~d}$ & $0.03 \mathrm{~d}$ \\
1 & $5.3 \mathrm{bcd}$ & $0.18 \mathrm{bcd}$ \\
2 & $7.1 \mathrm{bc}$ & $0.23 \mathrm{bc}$ \\
3 & $3.6 \mathrm{~cd}$ & $0.10 \mathrm{~cd}$ \\
4 & $18.6 \mathrm{a}$ & $0.52 \mathrm{a}$ \\
5 & $12.7 \mathrm{ab}$ & $0.38 \mathrm{ab}$ \\
6 & $4.2 \mathrm{~cd}$ & $0.10 \mathrm{~cd}$ \\
7 & $0.7 \mathrm{~d}$ & $0.03 \mathrm{~cd}$ \\
8 & $3.5 \mathrm{~cd}$ & $0.11 \mathrm{~cd}$ \\
9 & $9.8 \mathrm{ab}$ & $0.31 \mathrm{ab}$ \\
10 & $14.1 * *$ & $12.7 * *$ \\
\hline F Test (M) & $8.0 \mathrm{a}$ & $0.23 \mathrm{a}$ \\
\hline Mega-cutting position $(\mathbf{c m})(\mathbf{P})$ & $0.19 \mathrm{a}$ \\
$0-40$ & $6.2 \mathrm{a}$ & $0.17 \mathrm{a}$ \\
$40-80$ & $5.7 \mathrm{a}$ & $0.16 \mathrm{a}$ \\
$80-120$ & $5.3 \mathrm{a}$ & $0.24 \mathrm{a}$ \\
$120-160$ & $7.9 \mathrm{a}$ & $1.2^{\mathrm{ns}}$ \\
$160-200$ & $0.9^{\mathrm{ns}}$ & $1.0^{\mathrm{ns}}$ \\
\hline F Test (P) & $1.0^{\mathrm{ns}}$ & 13.6 \\
\hline F Test (MxP) & 54.7 & \\
\hline CV $(\%)$ &
\end{tabular}

Averages followed by the same letter in column, within each factor, do not differ by the Tukey's test at $5 \%$ probability level; ** - significant by $\mathrm{F}$ test at $1 \%$ probability level; ${ }^{\text {ns }}$ - not significant by the $\mathrm{F}$ test at $5 \%$ probability level. 

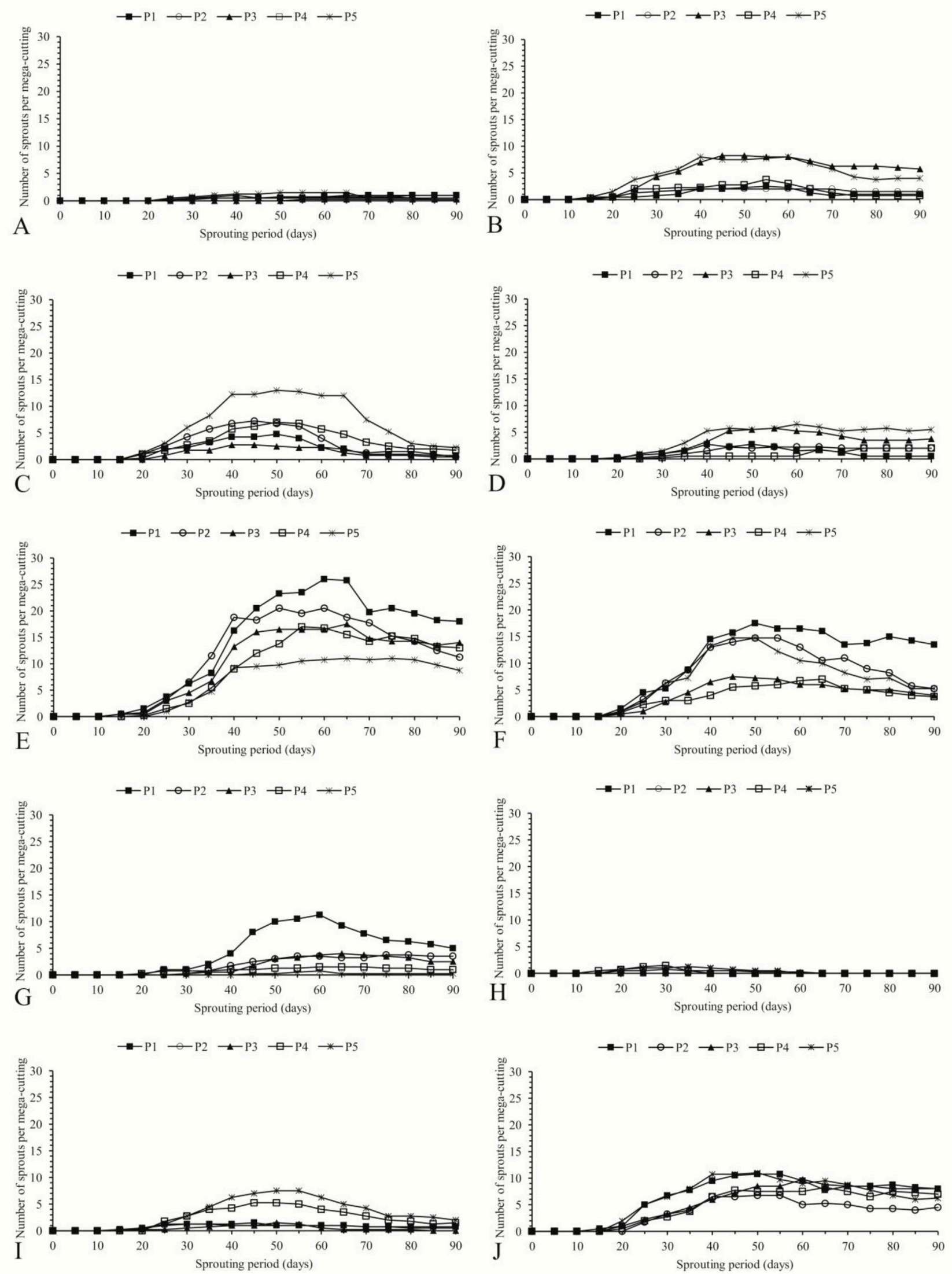

Figure 1. Average number of epicormic sprouts emitted per mother plant (A, mother plant 1; B, mother plant 2; C, mother plant 3; D, mother plant 4; E, mother plant 5; F, mother plant 6; G, mother plant 7; H, mother plant 8; I, mother plant 9; J, mother plant 10) and mega-cutting position (P1, position 0-40 cm; P2, position 40-80 cm; P3, position 80-120 cm; P4, position $120-160 \mathrm{~cm}$; $\mathrm{P} 5$, position 160-200 cm), from detached camu-camu branches in nursery with intermittent mist system. 
The sprouting speed index showed results similar to the number of sprouts per mega-cutting (Table 1). In general, mother plants with the highest number of emitted sprouts were also those with the highest emission speed and vice versa (Table 1).

The number of sprouts was strongly influenced by the genetic factor, or mother plant. According to Meier et al. (2012), the process of activating dormant sprouts is related to genetic and hormonal factors of the plant.
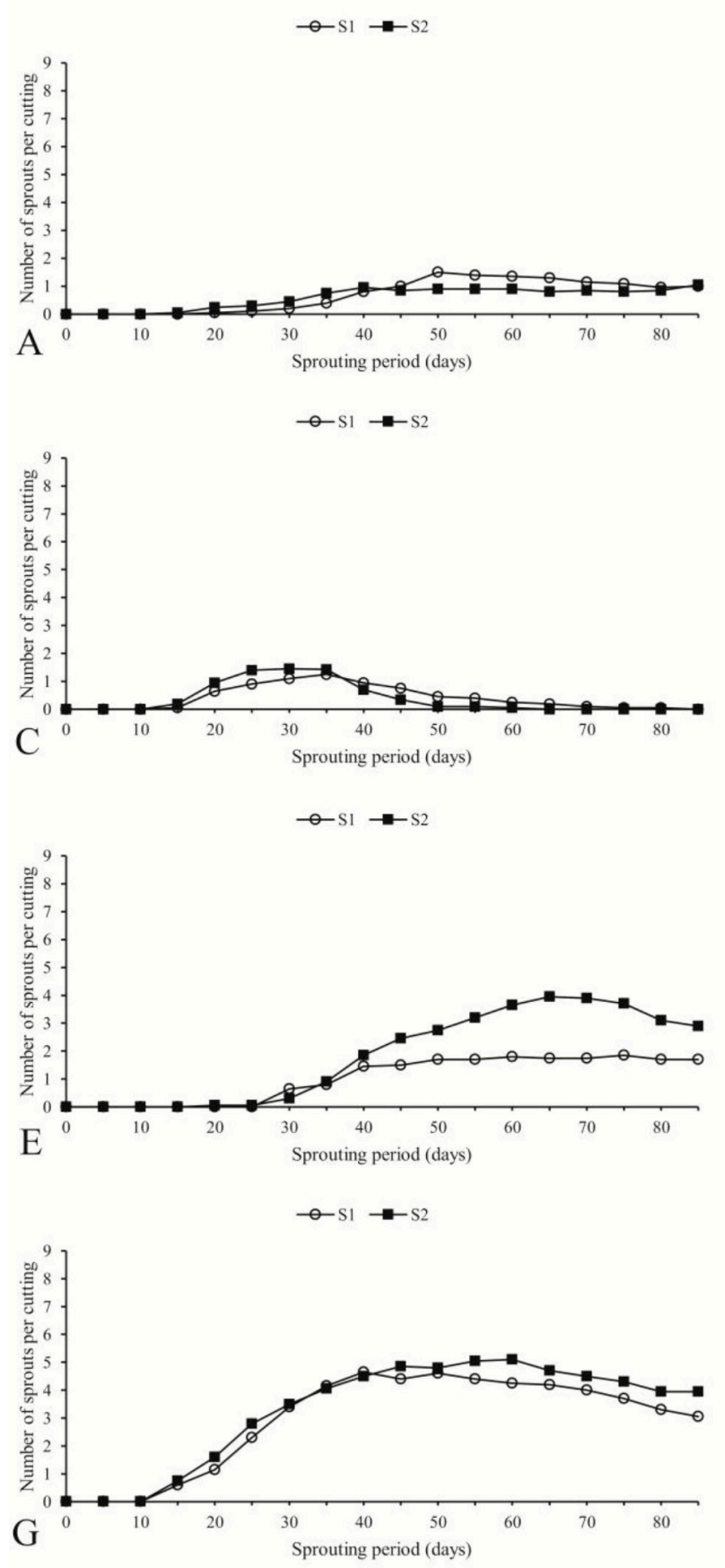

\section{Experiment 2}

The beginning of the emission of epicormic sprouts, as in experiment 1 , was between 10 to 15 days in most mother plant $\mathrm{x}$ substrate associations (Figure 2). Nascimento (2018) reported that camu-camu cuttings with $20 \mathrm{~cm}$ in length and in environment with intermittent mist start the emission of sprouts after 10 days.

The period of sprout emission stabilization was variable among mother plants. Mother plant 3 started to stabilize and reached peak of sprout emission earlier, between 25 and 35 days, while mother plant 5 was later, between 60 and 75 days. However, maximum sprout emission was reached on average at 52 days $( \pm 14)$.
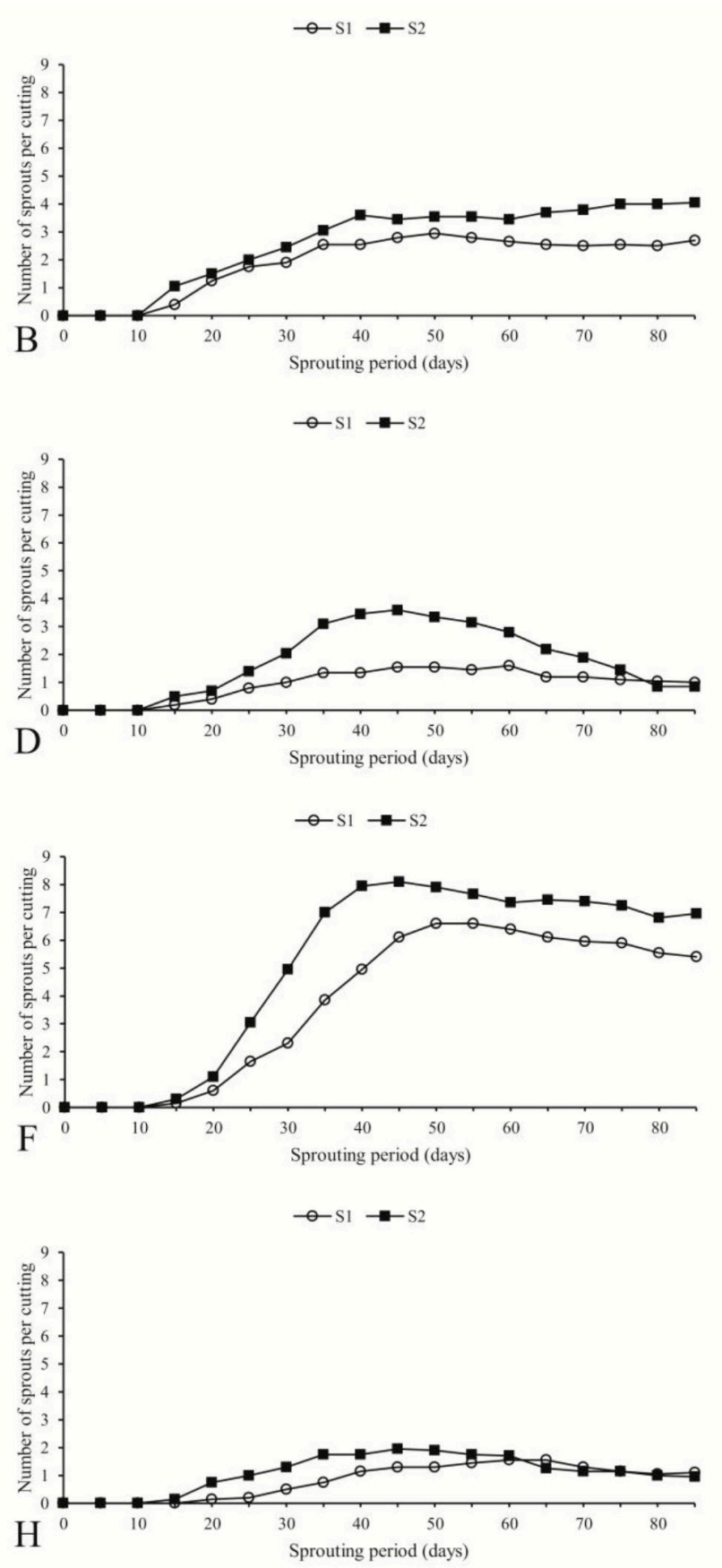

Figure 2. Average number of epicormic sprouts as a function of mother plant (A, mother plant 1; B, mother plant 2; C, mother plant 3; D, mother plant 4; E, mother plant 5; F, mother plant 6; G, mother plant 7; H, mother plant 8) and substrates (S1, commercial substrate; S2, non-commercial substrate), from detached camu-camu branches in nursery with intermittent mist system. 
The number, mean time and sprouting speed index did not show significant interaction effect between mother plant and substrate, but only for isolated factors, except for the number of sprouts and mean time in relation to substrate factor. The number of sprouts was higher for mother plant 6 (7.4), very different from results of mother plants $1,3,5$ and 8 , which had the lowest averages with, 1.3, 1.7, 2.3 and 1,7 sprouts, respectively (Table 2).
Delgado and Yuyama (2010) using similar propagating material, obtained, on average, two sprouts per cutting. Although this variable had averages lower than the previous experiment due to the shorter length and diameter of cuttings (reserve), this type of propagating material becomes viable because it allows the collection of greater number of cuttings, since its availability and amount is greater on the plant.

Table 2. Average number of epicormic sprouts (NEB), means sprouting time (MST) and sprouting speed index (SSI) from detached branches of different camu-camu mother plants using different substrates, referring to the period of 50 days of observation, under nursery conditions with intermittent mist system in Manaus, AM.

\begin{tabular}{cccc}
\hline Factors & NEB & $\begin{array}{c}\text { MST } \\
\text { (days) }\end{array}$ & $\begin{array}{c}\text { SSI } \\
\text { (sprout day }{ }^{-1} \text { ) }\end{array}$ \\
\hline Mother plant (M) & $1.3 \mathrm{e}$ & $35.0 \mathrm{ab}$ & $0.04 \mathrm{~d}$ \\
1 & $3.5 \mathrm{bc}$ & $27.2 \mathrm{bc}$ & $0.15 \mathrm{ab}$ \\
2 & $1.7 \mathrm{de}$ & $21.3 \mathrm{c}$ & $0.08 \mathrm{bcd}$ \\
3 & $2.7 \mathrm{~cd}$ & $28.6 \mathrm{bc}$ & $0.10 \mathrm{bc}$ \\
4 & $2.3 \mathrm{cde}$ & $40.4 \mathrm{a}$ & $0.06 \mathrm{~cd}$ \\
5 & $7.4 \mathrm{a}$ & $32.2 \mathrm{ab}$ & $0.25 \mathrm{a}$ \\
6 & $5.1 \mathrm{ab}$ & $29.3 \mathrm{bc}$ & $0.20 \mathrm{a}$ \\
7 & $1.7 \mathrm{de}$ & $32.1 \mathrm{ab}$ & $0.06 \mathrm{~cd}$ \\
8 & $19.3^{* *}$ & $5.6^{* *}$ & $18.0^{* *}$ \\
\hline F Test (M) & $2.9 \mathrm{a}$ & $31.3 \mathrm{a}$ & $0.10 \mathrm{~b}$ \\
\hline Substrate (S) & $3.5 \mathrm{a}$ & $30.2 \mathrm{a}$ & $0.13 \mathrm{a}$ \\
Commercial & $3.6^{\mathrm{ns}}$ & $0.4^{\mathrm{ns}}$ & $6.4^{*}$ \\
\hline Non-commercial & $1.2^{\mathrm{ns}}$ & $0.4^{\mathrm{ns}}$ & $0.9^{\mathrm{ns}}$ \\
\hline F Test (S) & 22.2 & 22.1 & 23.6 \\
\hline F Test (MxS) & & \\
\hline CV $(\%)$ &
\end{tabular}

Averages followed by the same letter in column, within each factor, do not differ by the Tukey test at $5 \%$ probability level; * and ** - significant by the $\mathrm{F}$ test at 5 and $1 \%$ probability levels, respectively; ${ }^{\mathrm{n}}$ - not significant by the $\mathrm{F}$ test at $5 \%$ probability level.

Regarding the mean sprouting time, mother plant 3 showed the lowest value (21.3 days); however, it also showed the lowest number of emitted sprouts (Table 2). The sprouting speed index had significant effect on both factors. Mother plants 6 and 7 obtained the highest averages, 0.25 and 0.20 sprouts day $^{-1}$, respectively. Regarding substrate, non-commercial proved to be superior, with average of 0.13 sprouts day ${ }^{-1}$, which may have occurred due to its physical and / or chemical condition that favored the sprouting speed, requiring further investigations.

It was observed that among mother plants, five showed rooting (1, 2, 6, 7 and 8). Mother plant 2 presented the most expressive percentage (77.5\%), and for this mother plant, rooting was $90 \%$ using non-commercial substrate and $65 \%$ using commercial substrate. Rodríguez et al. (2014) observed that the rooting of camu-camu cuttings was influenced by the genotypic variability of mother plants, which oscillated between 0 and $91 \%$.

\section{Experiment 3}

No effect of the interaction among factors (mother plant, type of cutting and IBA concentration) was observed for variables survival and rooting. Survival rate did not show significant differences between mother plant and type of cutting factors, but only between means of IBA concentrations (Table 3). The highest survival rate was observed in cuttings that were not treated with IBA(Figure 3 ), indicating a phytotoxic effect of the growth regulator. Goulart et al. (2008) also found IBA phytotoxicity in Eucalyptus grandis $\mathrm{x}$ E. urophylla clones, depending on the clone and growth regulator concentration. 
Table 3. Average survival rate and rooting of camu-camu cuttings from epicormic sprouts of different mother plants, types of cuttings and IBA concentrations after 90 days of observation under nursery conditions with intermittent mist system, in Manaus, AM.

\begin{tabular}{|c|c|c|}
\hline Factors & $\begin{array}{c}\text { Survival rate } \\
(\%)\end{array}$ & $\begin{array}{c}\text { Rooting } \\
(\%)\end{array}$ \\
\hline \multicolumn{3}{|c|}{ Mother plant (M) } \\
\hline 1 & $32.5 \mathrm{a}$ & $19.2 \mathrm{a}$ \\
\hline 2 & $38.3 \mathrm{a}$ & $20.0 \mathrm{a}$ \\
\hline F Test (M) & $0.4^{\mathrm{ns}}$ & $0.01^{\mathrm{ns}}$ \\
\hline \multicolumn{3}{|c|}{ Type of cutting ( $T)$} \\
\hline Basal & $37.5 \mathrm{a}$ & $28.3 \mathrm{a}$ \\
\hline Superior & $33.3 \mathrm{a}$ & $10.8 \mathrm{~b}$ \\
\hline Teste F (T) & $0.2^{\mathrm{ns}}$ & $9.7 * *$ \\
\hline \multicolumn{3}{|c|}{ IBA concentration $\left(\mathrm{mg} \mathrm{kg}^{-1}\right)(\mathrm{C})$} \\
\hline 0 & - & $30.0 \mathrm{a}$ \\
\hline 500 & - & $13.3 \mathrm{a}$ \\
\hline 1.000 & - & $18.3 \mathrm{a}$ \\
\hline 2.000 & - & $16.7 \mathrm{a}$ \\
\hline F Test $(\mathrm{C})$ & $3.0 *$ & $1.6^{\mathrm{ns}}$ \\
\hline F Test (MxT) & $2.6^{\mathrm{ns}}$ & $1.9^{\mathrm{ns}}$ \\
\hline F Test (MxC) & $0.3^{\mathrm{ns}}$ & $0.2^{\mathrm{ns}}$ \\
\hline F Test (TxC) & $0.6^{\mathrm{ns}}$ & $1.2^{\mathrm{ns}}$ \\
\hline F Test (MxTxC) & $0.4^{\mathrm{ns}}$ & $0.4^{\mathrm{ns}}$ \\
\hline $\mathrm{CV}(\%)$ & 50.2 & 74.9 \\
\hline
\end{tabular}

Averages followed by the same letter in column, within each factor, do not differ by the Tukey test at 5\% probability level; * and ** - significant by the $\mathrm{F}$ test at 5 and $1 \%$ probability levels, respectively; ns - not significant by the $\mathrm{F}$ test at $5 \%$ probability level.

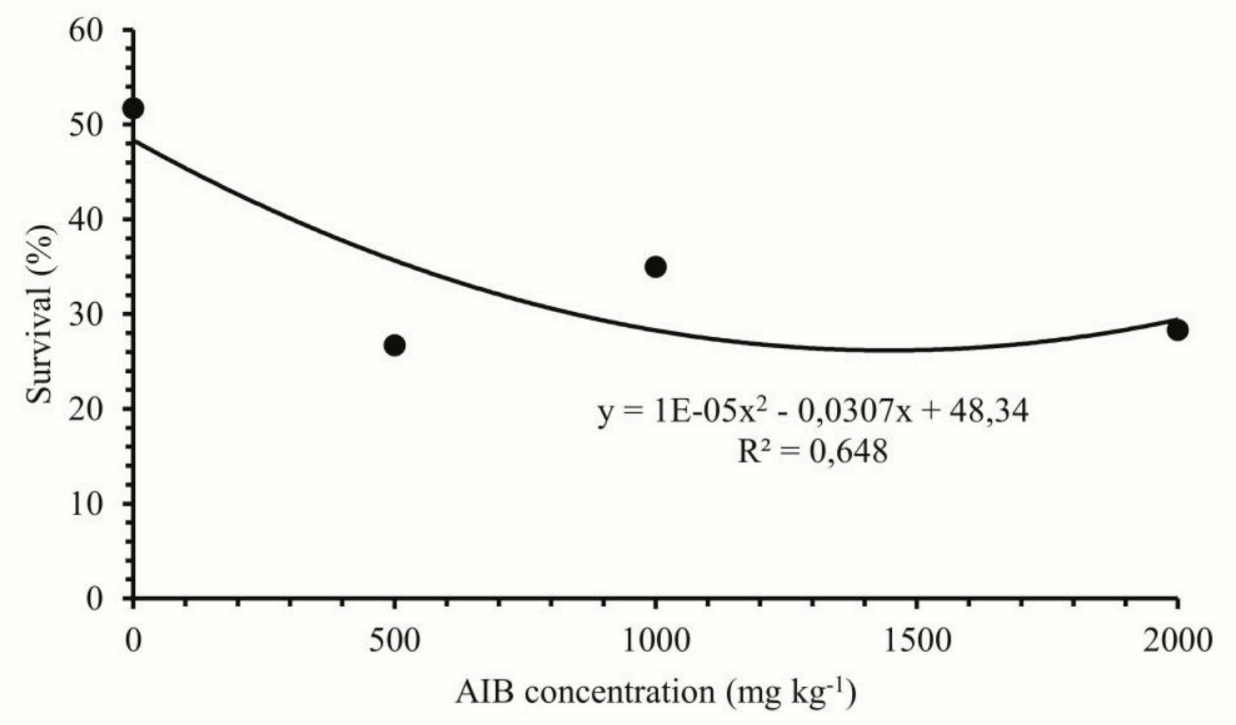

Figure 3. Survival rate of camu-camu cuttings from epicormic sprouts as a function of IBA concentrations after 90 days of observation under nursery conditions with intermittent mist system, in Manaus, AM. 
In relation to rooting, mother plant and IBA concentration factors did not show statistical differences among their levels (Table 3). Nevertheless, there was a tendency to decrease rooting when cuttings were treated with IBA. In this case, the lack of significant difference probably occurred due to the high coefficient of variation (74.9\%), which probably was due to uncontrolled and unknown factors. Epicormic sprout cuttings of Ilex paraguariensis (BITENCOURT et al., 2009), quiri (Paulownia fortunei var. mikado) (STUEPP et al., 2014) and guaricica (Vochysia bifalcata) (RICKLI et al., 2015) also did not show favorable results when applying IBA to induce adventitious roots.

As for the type of cutting, those from the basal portion showed significantly higher results (28.5\%). According to Hartmann et al. (1996), apical cuttings have meristematic cells with more active metabolism, in addition to less lignification and amount of phenolic compounds, which favors rooting and sprouting. However, they may show lower performance due to the greater predisposition to lose water. Lima et al. (2013) reported that basal and median semi-woody Camellia sinensis cuttings have greater rooting capacity, compared to apical. On the other hand, mini-cuttings from the apical portion of Eucalyptus benthamii showed superior rooting (56.24\%), compared to those of the median (18.74\%) and basal portions (14.58\%) (BENIN et al., 2013).
It was observed that the amount of cuttings with callus and sprouts in shoots was quite reduced. Only 2.5\% of mother plant 2 cuttings formed callus and $5.8 \%$ emitted sprouts. For mother plant 3, percentages were around 8.3\% (callus) and 5\% (sprouts).

\section{Experiment 4}

No effect of the interaction among factors (mother plant, hydroretentive polymer and environment) was observed for survival, sprouting and rooting variables.

The survival of cuttings was significantly higher in environment with intermittent mist $(36.7 \%)$ and in substrate without the presence of hydroretentive polymer $(32.2 \%)$, without significant differences among mother plants (Table 4). Azevedo et al. (2015) studied Eucalyptus spp., and observed that as the dose of hydroretentive polymer increased, the survival of cuttings decreased.

Sprouting and rooting showed significant differences only for environment factor, with the best results in the condition of intermittent mist, whose values were 30.0 and $36.7 \%$, respectively (Table 4 ). Nascimento (2018) recommends this type of environment for the propagation of camu-camu using the cutting method.

Table 4. Averages of survival, sprouting and rooting of camu-camu cuttings from epicormic sprouts using different mother plants, environments and hydroretentive polymer concentrations after 90 days of observation in Manaus, AM.

\begin{tabular}{|c|c|c|c|}
\hline Factors & $\begin{array}{c}\text { Survival rate } \\
(\%)\end{array}$ & $\begin{array}{c}\text { Sprouting } \\
(\%)\end{array}$ & $\begin{array}{c}\text { Rooting } \\
(\%)\end{array}$ \\
\hline \multicolumn{4}{|c|}{ Mother plant (M) } \\
\hline 1 & $33.3 \mathrm{a}$ & $25.0 \mathrm{a}$ & $30.0 \mathrm{a}$ \\
\hline 2 & $30.0 \mathrm{a}$ & $30.0 \mathrm{a}$ & $30.0 \mathrm{a}$ \\
\hline 3 & $16.7 \mathrm{a}$ & $11.7 \mathrm{a}$ & $15.0 \mathrm{a}$ \\
\hline F Test (M) & $2.1^{\mathrm{ns}}$ & 2.5 ns & $2.1^{\mathrm{ns}}$ \\
\hline \multicolumn{4}{|c|}{ Environment (E) } \\
\hline $\begin{array}{l}\text { Mini- } \\
\text { greenhouse }\end{array}$ & $16.7 \mathrm{~b}$ & $14.4 \mathrm{~b}$ & $13.3 \mathrm{~b}$ \\
\hline Mist & $36.7 \mathrm{a}$ & $30.0 \mathrm{a}$ & $36.7 \mathrm{a}$ \\
\hline F Test (A) & $11.0 * *$ & $4.7 *$ & $14.9 * *$ \\
\hline \multicolumn{4}{|c|}{ Hydroretentive polymer $\left(\mathrm{g} \mathrm{L}^{-1}\right)(\mathrm{H})$} \\
\hline 0 & $32.2 \mathrm{a}$ & $25.6 \mathrm{a}$ & $28.9 \mathrm{a}$ \\
\hline 2 & $21.1 \mathrm{~b}$ & $18.9 \mathrm{a}$ & $21.1 \mathrm{a}$ \\
\hline F Test $(\mathrm{H})$ & $4.9 *$ & $1.5^{\mathrm{ns}}$ & $2.9^{\mathrm{ns}}$ \\
\hline F Test (MxE) & $1.4^{\mathrm{ns}}$ & $1.3^{\mathrm{ns}}$ & $2.3^{\mathrm{ns}}$ \\
\hline F Test $(\mathrm{MxH})$ & $0.1^{\mathrm{ns}}$ & $0.2^{\mathrm{ns}}$ & $0.1^{\mathrm{ns}}$ \\
\hline F Test $(\mathrm{ExH})$ & $2.1^{\mathrm{ns}}$ & $1.6^{\mathrm{ns}}$ & $0.9^{\mathrm{ns}}$ \\
\hline F Test (MxExH) & $0.9^{\mathrm{ns}}$ & $0.5^{\mathrm{ns}}$ & $0.4^{\mathrm{ns}}$ \\
\hline $\mathrm{CV}(\%)$ & 55.7 & 75.8 & 58.5 \\
\hline
\end{tabular}

Averages followed by the same letter in column, within each factor, do not differ by the Tukey test at $5 \%$ probability level; * and ** - significant by the $\mathrm{F}$ test at 5 and $1 \%$ probability levels, respectively; ${ }^{\mathrm{ns}}$ - not significant by the $\mathrm{F}$ test at $5 \%$ probability level. 
Regardless of factors, callus formation was null for mother plants 1 and 2, and only $1.6 \%$ of cuttings of mother plant 3.

Most of the times, both in this experiment and in the previous one, rooting was reduced, with values below $40 \%$. Similar results were obtained by Nascimento (2018), who reported the need for further investigations in order to improve the propagation of camu-camu by cuttings to improve the production of seedlings of selected material on a large scale.

\section{Conclusions}

Mother plant is more relevant than mega-cutting position in the branch or type of substrate in the epicormic camu-camu sprouting.

Cuttings from the basal portion of the sprout have greater rooting potential than those from the upper portion without the need for indolbutyric acid.

Environment with intermittent mist irrigation and substrate without the presence of hydroretentive polymer are more suitable for the propagation of camu-camu by cuttings.

The vegetative rescue by means of epicormic sprouts in mega-cuttings and cuttings of detached branches presents potential application for the clonal propagation of camu-camu, requiring improvement in order to increase its efficiency.

\section{Acknowledgments}

To the Coordination for the Improvement of Higher Education Personnel (Capes), for the granting of scholarship to the first and third author and to the National Institute for Research in the Amazon (INPA) for providing conditions to carry out this research.

\section{References}

ALMEIDA, F.D.; XAVIER, A.; DIAS, J.M.M. Propagação vegetativa de árvores selecionadas de Eucalyptus cloeziana F.Muell.por estaquia. Revista Árvore, Viçosa, MG, v.31, n.3, p.445-453, 2007.

AZEVEDO, G.T.D.O.S.; DE SOUZA, A.M.; DE AZEVEDO, G.B.; DECERQUEIRA, P.H.A. Enraizamento de miniestacas de eucalipto com diferentes doses de polímero hidroretentor incorporado ao substrato. Scientia Forestalis, Piracicaba, v.43, n.108, p.773-780, 2015.
BACCARIN, F.J.B.; BRONDANI, G.B.; ALMEIDA, L.V.; VIEIRA, I.G.; OLIVEIRA, L.S.; ALMEIDA, M. Vegetative rescue and cloning of Eucalyptus benthamii selected adult trees. New Forests, Berlin, v.46, p.465483, 2015.

BENIN, C.C.; PERES, F.S.B.; GARCIA, F.A.O. Enraizamento de miniestacas apicais, intermediárias e basais em clones de Eucalyptus benthamii. Floresta, Curitiba, v.43, n.3, p.421-428, 2013.

BITENCOURT, J.D.; ZUFFELLATO-RIBAS, K.C.; WENDLING, I.; KOEHLER, H.S. Enraizamento de estacas de erva-mate (Ilex paraguariensis A.St.Hill.) provenientes de brotações rejuvenescidas. Revista Brasileira de Plantas Medicinais, Botucatu, v.11, n.3, p.277-281, 2009.

BORGES JÚNIOR, N., MARTINS-CORDER, M.P., SOBROSA, R.D.C.; SANTOS, E.M.D. Rebrota de cepas de árvores adultas de acácia-negra (Acacia mearnsii De Wild.). Revista Árvore, Viçosa, MG, v.28, n.4, p.611615, 2004.

CHAGAS, E.A.; BACELAR-LIMA, G.; CARVALHO, A.S.; RIBEIRO, M.I.G.; SAKAZAKI, R.T.; NEVES, L.C. Propagação do camu-camu (Myrciaria dubia (H.B.K.) McVaugh). Revista Agroambiente On-line, Boa Vista, v.6, n.1, p.67-73, 2012.

CRUZ, C.A. Efecto de los ácidos naftalenacético e indolbutírico en el enraizamiento de estacas de Myrciaria dubia (HBK) Mc Vaugh, camu camu. Folia Amazonica, Iquitos, v.14, n.2, p.27-33, 2005.

DELGADO, J.P.M.; YUYAMA, K. Comprimento de estaca de camu-camu com ácido indolbutírico para a formação de mudas. Revista Brasileira de Fruticultura, Jaboticabal, v.32, p.522-526, 2010.

DIAS, P.C.; XAVIER, A.; OLIVEIRA, L.S.; FÉLIX, G.A.; PIRES, I.E. Resgate vegetativo de árvores de Anadenanthera macrocarpa. Cerne, Lavras, v.21, p.8389, 2015.

FACHINELLO, J.C.; HOFFMANN, A.; NACHTIGAL, J.C.KERSTEN, E. Propagação vegetativa por estaquia. In: FACHINELLO, J.C.; HOFFMANN, A.; NACHHTIGAL, J.C. (Ed.). Propagação de plantas frutíferas. Brasília: Embrapa, 2005. 221p.

GENTIL, D.F.O.; SILVA, W.R.; FERREIRA, S.A.N. Conservação de sementes de Myrciaria dubia (H.B.K.) McVaugh. Bragantia, Campinas, v.63, n.3, p.421-430, 2004. 
GOULART, P.B.; XAVIER, A.; CARDOSO, N.Z. Efeito dos reguladores de crescimento AIB e ANA no enraizamento de miniestacas de clones de Eucalyptus grandis X Eucalyptus urophylla. Revista Árvore, Viçosa, MG, v.32, n.6, p.1051-1058, 2008.

HAFLE, O.M.; CRUZ, M.C.M.; RAMOS, J.D.; RAMOS, P.S.; SANTOS, V.A. Produção de mudas de maracujazeiro-doce através da estaquia utilizando polímero hidrorretentor. Revista Brasileira de Ciências Agrárias, Recife, v.3, n3, p.232-236, 2008.

HARTMANN, H.T.; KESTER, D.E.; DAVIES JUNIOR, F.T.; GENEVE, R.L. Plant propagation: principles and pratices .6.ed. New Jersey: Prentice Hall, 1996. 770p.

KIBBLER, H.; WILLIAMS, C.M.; WILLIAMS, R.R.; JOHNSTON, M.E. Inhibition of adventitious rooting in Backhousia citriodora F.Muell.cuttings correlate with the concentration of essential oil. Journal of Horticultural Science \& Biotechnology, Ashford, v.77, n.6, p.705-711, 2002.

LABOURIAU, L.G. A germinação das sementes. Washington: Secretaria Geral da Organização dos Estados Americanos, 1983. 174p.

LIMA J.D.; BOLFARINI A.C.B.; SILVA, S.H.M.G.; MORAES W.S. Propagação de Camellia sinensis: efeito do genótipo, estaca, substrato, recipiente e ácido indolbutírico. Horticultura Brasileira, Brasília, DF, v.31, p. 74-79, 2013.

MAGUIRE, J.D. Speed of germination-aid in selection and evaluation for seedling emergence and vigor. Crop Science, Madison, v.2, p.176-177, 1962.

MEIER, A.R.; SAUNDERS, M.R.; MICHLER, C.H. Epicormic buds in trees: a review of bud establishment, development and dormancy release. Tree Physiology, Oxford, v.32, p.565-584, 2012.

MOREIRA, R.A.; RAMOS, J.D.; CRUZ, M.C.M.; VILLAR, L.; HAFLE, O.M. Ácido indolbutírico e polímero hidroabsorvente no enraizamento de estacas de amoreira-preta. Scientia Agraria Paranaensis, Marechal Cândido Rondon, v.11, n.1, p.74-81, 2012.

NASCIMENTO, B.; SÁ, A.C.S.; LEMOS, L.B.; ROSA, D.P.; PEREIRA, M.O.; NAVROSKI, M.C. Three epicormic shoot techniques in I.paraguariensis mother trees and its cutting according to the material rejuvenation degree. Cerne, Lavras, v.24, n.3, p.240-248, 2018.
NAVROSKI, M.C.; ARAUJO, M.M.; FIOR, C.S.; CUNHA, F.S.; BERGHETTI, A.L.P.; PEREIRA, M.O. Uso de hidrogel possibilita redução da irrigação e melhora o crescimento inicial de mudas de Eucalyptus dunnii Maiden. Scientia Forestalis, Piracicaba, v.43, n.106, p.467-476, 2015.

PANDURO, P.M.; RIVA, R.R.; RENGIFO, S.E.; DELGADO, V.C.; VILLACRES, V.J.; GONZÁLEZ, C.A.; INGA, S.H.; LÓPEZ, U.A.; FARROÑAY, P.R.; VEJA, V.R.; LINARES, B.C. Sistema de producción de camu camu en restinga. Iquitos: IIAP, 2001. 143p.

PETERS, C.M.; VÁSQUEZ, A. Estúdios ecológicos de camu-camu (Myrciaria dúbia). I. producción de frutos en poblaciones naturales. Acta Amazonica, Manaus, v.16/17, p.161-174, 1987.

RICKLI, H.C.; BONA, C.; WENDLING, I.; KOEHLER, H.S.; ZUFFELLATO-RIBAS, K.C. Origem de brotações epicórmicas e aplicação de ácido indolilbutírico no enraizamento de estacas de Vochysia bifalcata Warm. Ciência Florestal, Santa Maria, v.25, n.2.p.385-393, 2015.

RODRÍGUEZ, C.A.; CHAGAS, E.A.; SÁNCHEZCHOY, J.; SANTOS, V.A.; LOZANO, R.M.B.; RÍOS, G.S. Capacidad de enraizamiento de plantas matrices promisorias de Myrciaria dubia (Kunth) Mc Vaugh en cámaras de subirrigación. Revista Ceres, Viçosa, MG, v.61, n.1, p.134-140, 2014.

SILVA, F.A.S.; AZEVEDO, C.A.V. The Assistat software version 7.7 and its use in the analysis of experimental data. African Journal of Agricultural Research, Nairobi, v.11, n.39, p.3733-3740, 2016.

SILVA, F.V.C.; CASTRO, A.M.; CHAGAS, E.A.; PESSONI, L.A. Propagação vegetativa de camu-camu por estaquia: efeito de fitorreguladores e substratos. Revista Agro@mbiente On-line, Boa Vista, v.3, n.2, p.92-98, 2009.

STUEPP, C.A.; BITENCOURT, J.; WENDLING, I.; KOEHLER, H.S.; RIBAS, K.C.Z. Métodos de resgate e idades cronológicas de plantas-matrizes no enraizamento de brotações epicórmicas de Ilex paraguariensis. Ciência Florestal, Santa Maria, v.27, n.4, p.1409-1413, 2017.

STUEPP, C.A.; BITENCOURT, J.; WENDLING, I.; KOEHLER, H.S.; ZUFFELLATO-RIBAS, K.C. Indução de brotações epicórmicas por meio de anelamento e decepa em erva-mate. Ciência Florestal, Santa Maria, v.26, n.3, p.1009-1022, 2016. 
STUEPP, C.A.; ZUFFELLATO-RIBAS，K.C.; WENDLING, I.; KOEHLER, H.S.; BONA, C. Vegetative propagation of mature dragon trees through epicormic shoots. Bosque, Valdivia, v.35, n.3, p.337-345, 2014. (1)

WENDLING, I.; BRONDANI, G.E.; BIASSIO, A.; DUTRA, L.F. Vegetative propagation of adult Ilex paraguariensis trees through epicormic shoots. Acta Scientiarum.Agronomy, Maringá, v.35, n.1, p.117-125, 2013.
WENDLING, I.; DUTRA, L.F.; HOFFMANN, H.A.; BETTIO, G.; HANSEL, F. Indução de brotações epicórmicas ortotrópicas para a propagação vegetativa de árvores adultas de Araucaria angustifolia. Agronomía Costarricense, San José, v.33, n.2, p.309-319, 2009.

YUYAMA, K.A.; AGUIAR, J.P.L.; YUYAMA, L.K.O. Camu-camu: um fruto fantástico como fonte de vitamina C. Acta Amazonica, Manaus, v.32, n.1, p.169-174, 2002. 